set to with renewed energy to pursue his vision for the journal. He enlarged the staff, and arranged to supply Le Monde with regular articles about science. Nature also sponsored conferences in the liveliest areas of science and technology; these were held in Cambridge (UK), Boston, Paris, Tokyo and elsewhere, and attracted large audiences.

Editorial offices in France, Germany and Japan followed, and the journal took on a truly international aspect. Its circulation rose to 57,000, and its reputation likewise burgeoned. Maddox had come close to his professed ideal - to ensure that Nature would become indispensable reading, and that every scientist (and many others too) would await its weekly delivery in the post with keen anticipation.

Maddox abhorred stasis: he was an endless source of ideas, many brilliant, others dismaying to his staff (although often his aim was only to keep them on their toes). His restless eye for a scientific or journalistic coup led him on occasion into deep waters. Once in a while he would overrule a colleague and insist that a controversial manuscript be published, despite anguished objections in the office and the firm opinions of reviewers. Once or twice such papers were juxtaposed by a referee's dissenting evaluation.

The most notorious such episode, which occurred in 1988, centred on a paper from the laboratory of Jacques Benveniste in Paris, purporting to show that a substance, diluted to the point at which not one of its molecules remained in the assay mixtures, could still exert its biological effect. Maddox published the paper, along, shortly afterwards, with a rebuttal based on a visit to Benveniste's laboratory by himself, an American referee, and the well-known magician James (the Amazing) Randi. A correspondent wrote that it was at last clear to him how Nature selected papers for publication: they were chosen, he now surmised, by the editor, a conjuror and his rabbit. Maddox relished the uproar that followed, and remained unrepentant.

As science itself continued to grow, so did the demand for new publications. Nature and other high-profile journals could absorb only a few of the high-quality papers now seeking an outlet. Hence the impetus for the launch of monthly companion journals to Nature, to accommodate papers that the mother journal had to decline for lack of space, or that were deemed too specialized for the broad appeal at which it had always aimed. Nature Genetics was the first to appear, in 1992, and was an instant success. These

Brenda and John Maddox in the early 1960s. publications, which bear the Nature name but are editorially independent, now number 15 research journals and 15 review journals.

In 1996, John Maddox was knighted for his services to science, and in 2000 he was elected an honorary fellow of the Royal Society. It was widely recognized that he had represented the interests of science and scientists nationally and internationally through his books, editorials in Nature, articles in the press, public lectures and appearances on television and radio. On occasion, he undoubtedly caused government departments to reconsider science policy; he was also fearless in taking on what he held to be irresponsible reporting, as when he roundly defeated The Sunday Times in its espousal of a misguided and socially dangerous theory of the causation of AIDS. He retired from Nature in 1995, after a total of 22 eventful years in the editorial chair

Maddox's several books, especially What Remains to be Discovered (Free Press, 1997), attracted wide attention and were unfailingly stimulating. He was an inveterate traveller, who seldom turned down a request to deliver a lecture or take part in a conference, wherever it might be. He was responsible for launching an accessible monthly digest of Nature (now alas defunct) for distribution in Russia and for bringing science to the celebrated literary festival at Hay-on-Wye, near his weekend cottage in Wales, where he also served as a conscientious councillor.

John Maddox was engaging and stimulating company: his range of friends extended far beyond the confines of science, and following his retirement many of his protégés in the Nature office and elsewhere remained in close touch. In his slightly hesitant and invariably courteous way, he could be severe on the workshy or complacent, but to those who shared his enthusiasm he gave unstinting support. He leaves his wife Brenda, a distinguished journalist and biographer, their son and daughter, who both followed their parents into notable careers in journalism, and a son and daughter from a previous relationship.

\section{Walter Gratzer}

Walter Gratzer was the first regular News \& Views correspondent appointed by John Maddox. He is at King's College London, The Randall Division of Cell and Molecular Biophysics, New Hunt's House, Guy's Campus, London SE1 1UL, UK. e-mail:walter.gratzer@gmail.com

\title{
A publisher's perspective
}

During the latter part of his first period as the editor of Nature (1966-73), John Maddox combined his job with responsibilities as managing director of Macmillan Journals - a division of what became Macmillan Publishers Ltd.

As such, Maddox's influence within the company spread beyond Nature and indeed far beyond the other journals it published. At that time, Macmillan was living off its past as publisher not only of Nature, founded in 1869, but of such authors as Henry James, Thomas Hardy, Rudyard Kipling, W. B. Yeats and John Maynard Keynes. The list of books and journals was fading, however, and had not been renewed, and the company had been overtaken by newer, more assertive publishing houses.

Maddox believed that, if a newcomer had enthusiasm and a

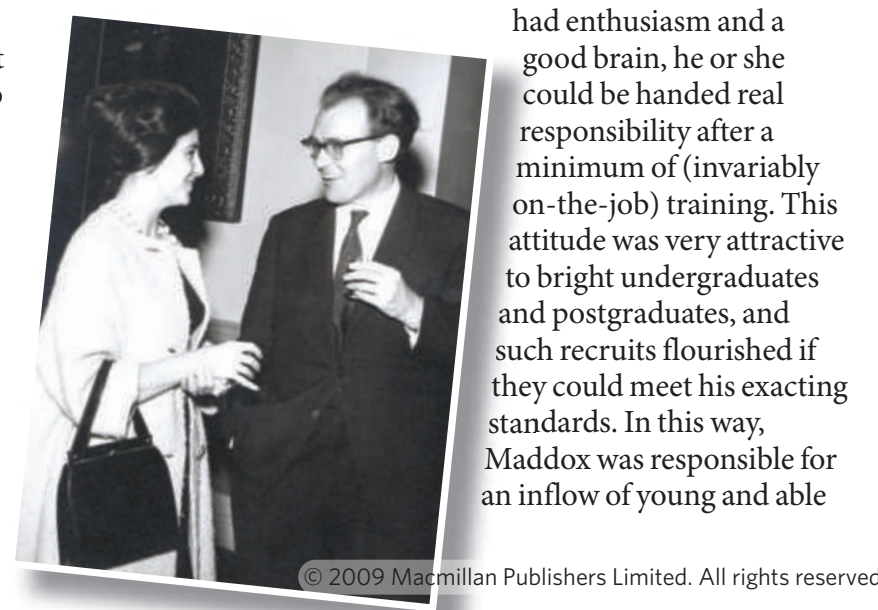

publishers and scientists into Macmillan.

During the late 1960s and early 1970s, this policy dramatically enlivened an ageing organization and kick-started it into growth. It was not always possible for Maddox's charm and Macmillan's growth to accommodate the increasing ambitions of so much talent. Some staff members inevitably left after a few years, usually for great success elsewhere in publishing. But many stayed, and Macmillan was enriched and rejuvenated each year as a result.

Maddox was also responsible for a range of new journals, such as Education and Training, Drugs and Society and Science Studies.

Science never claimed him exclusively. He participated fully in other expansionist plans, most notably being involved in reference books for all manner of academic disciplines, most of them outside the sciences. His watch as managing director also saw the experiment of publishing additional biology and physics papers in two companion weekly journals, Nature New Biology and Nature Physical Sciences. This was an idea that was ahead of its time, at least commercially, and it was discontinued. But it was successfully revisited in the early 1990s, and when Maddox retired in 1995, three monthly research journals existed under the Nature banner (now there are many more).

Even before his appointment as director of the Nuffield Foundation in 1975, Maddox 
had been active in a wide range of public-service appointments, and in 1974 had initiated the much-praised fortnightly programme Scientifically Speaking for what is now BBC Radio 3. Maddox's great ambition, however, was to make Nature more accessible and to reach more readers, and when he returned again as editor in 1980 he devoted his main energies to that end. His eye for raw ability remained: in large part through his encouragement of bright and committed staff, Nature prospered as never before.

If his energy challenged and exhausted (and sometimes provoked) his younger colleagues, and if his motorway driving terrified the older ones, John Maddox's enthusiasm proved contagious and he remained admired and forgiven in exactly the right proportions until his retirement. $\mathrm{He}$ was intolerant of boredom and incapable of boring anyone else. A kind, very clever man, his friendship was treasured, and with pride, by many.

\section{Nicholas Byam Shaw}

Nicholas Byam Shaw joined Macmillan Publishers Ltd in 1964, and was managing director from 1969 to 1990.

\section{Maddox by his successor}

It was early 1980 and the news was astonishing. John Maddox was coming back to be, for the second time, the editor of Nature.

To appreciate just how astonishing this was, you have to know about certain negative-sounding facts that some would say shouldn't be part of a tribute. But Maddox saw journalism, and his editorship, as above all being about uncovering truths, however uncomfortable.

At the time the news broke, the editor of Nature, David "Dai” Davies, had just decided to move on after seven years. Then a junior editor in the physical sciences, I was as concerned as the rest of my editorial colleagues about who might take over. As part of a consultative procedure, we'd seen the names on the shortlist, and were underwhelmed. To judge by what happened next, Macmillan's then managing director Nicholas Byam Shaw, whose own tribute to Maddox precedes this one, wasn't that keen on them either.

Dai Davies had had the task of taking over Nature from Maddox in 1973. Maddox had made the journal very much his own fiefdom over a period of seven years, and had left, so rumour had it, under something of a cloud. Indeed, I was told on my own first arrival at Nature in 1979 that one of our principal agendas was to restore the journal's reputation following Maddox's (as it was described) over-involvement, which had resulted in sometimes whimsical decision-making and delays in the handling of scientific papers.

So, a year or so later, you can imagine my surprise, and the consternation (leading to at least one departure) of more senior staff, when Byam Shaw, sweeping aside the shortlist and all consultation, announced that the new editor was to be John Maddox. I'd prefer not to speculate on what Dai Davies's feelings were, although I have no doubt that he handled the transition with decency and professionalism.

So Maddox took over, and Nature proceeded to do what it had done for much of his previous editorship. It thrived.

As I recall from my time as physicalsciences editor (I moved on to launch Physics World in 1988), Maddox did not involve

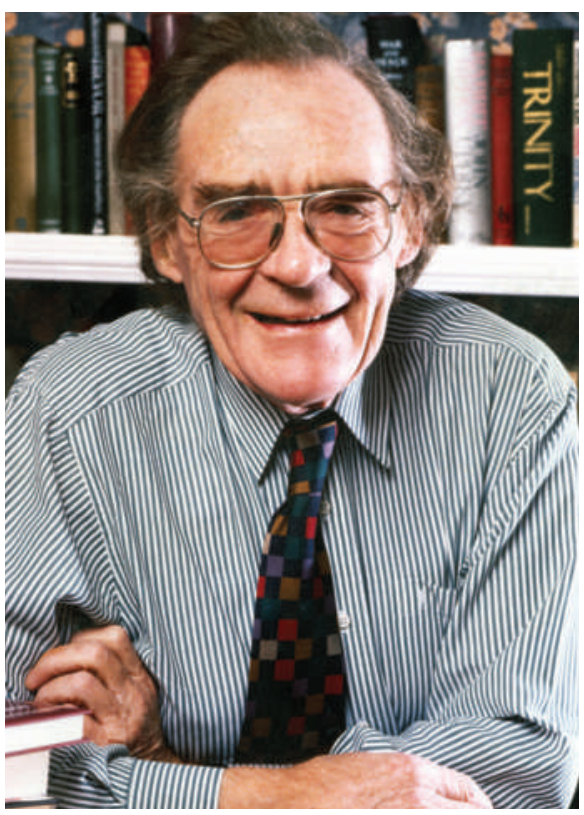

Retired and knighted, 1996.

himself much in decisions over scientific papers. Nevertheless, as he described on his final retirement (see Nature 378, 521-523; 1995), it was he, when he first became Nature's editor in 1966, who had transformed the assessment of such manuscripts from a process based on word-of-mouth recommendations to a system based on peer review. By the time he took over again from Davies, that system was less dependent on the editor and far more dependent on specialist editors in close contact with their respective communities - as it still is.

Despite his original establishment of the peer-review process at Nature, Maddox always had strong reservations about its conservatism. These were perhaps best reflected in his view that the Watson and Crick paper on the structure of DNA wouldn't pass muster under the current system. That paper was published as a result of recommendations by Lawrence Bragg, the head of Watson and Crick's laboratory, and John Randall. (The idea of Nature publishing a paper on the recommendations of the head of the authors' lab is nowadays, of course, sadly but appropriately laughable.)

But, as Maddox's redoubtable and indispensable assistant Mary Sheehan knew only too well - as did some authors who appealed to him to reverse his staff's decisions - committing himself to close involvement with even a few manuscripts was usually a recipe for aeons of delay. Indeed, I fully expect to be told that a pile of stillunanswered appeals has been discovered in the back of his car. On the other hand, he was also delighted occasionally to spot a really important paper and ensure its processing and publication at record-breaking speed.

Although Maddox had learned to delegate the assessment of submitted papers, he worried that his staff were, like referees, too conservative, and also (especially in hot areas of biology), too intent on achieving high impact factors and not ready enough to recognize bold ideas. I suspect there isn't an editor anywhere who doesn't worry about missing great new ideas, and we all have ways of trying to address the issue. Maddox had the willingness and authority very occasionally to ignore or even abandon the peer-review system when he was convinced that it would do nothing but delay publication. He ignored it in publishing the cosmological ideas of Fred Hoyle and colleagues - Hoyle was just the sort of brilliantly unconventional scientist whom Maddox respected most and abandoned it altogether in publishing the first, controversial hominid discoveries made by Richard Leakey at the Olduvai Gorge.

But it was as a journalist that Maddox most made his mark as Nature's editor, in both of his incarnations. The journal's significant increase in international circulation in the 1980s and 1990s during his second stint reflected not only strong marketing but also the impact of his journalistic instincts at play. And I mean 'play', rather than work. Like every Editor of Nature (and many of their colleagues), he worked ridiculous hours, but knew that the secret of survival was, above all, simply to enjoy the work. One of his favourite stated reasons for embarking on a controversial course of action was that it would be 'Fun' - a Maddoxian term received by colleagues with an equal measure of glee and foreboding.

Throughout his editorships, he was fecund in his writing, and brilliantly voracious in his scientific interests. Often more reliant on his 